Contributions:

A Study design/planning

B Data collection/entry

C Data analysis/statistics

D Data interpretation

E Preparation of manuscript

F Literature analysis/search

$G$ Funds collection

\title{
EFFECT OF SOUND INTENSITY ON LEVEL OF ACTIVATION IN AUDITORY CORTEX AS MEASURED BY FMRI
}

\author{
Tomasz Wolak ${ }^{A B C D E F}$, Katarzyna Ciesla ${ }^{A B C D E F}$, Joanna Wojcik ${ }^{B E}$, \\ Henryk Skarzynski ${ }^{A G}$
}

World Hearing Center, Institute of Physiology and Pathology of Hearing, 10 Mochnackiego Street, 02-042 Warszawa, Poland

Corresponding author: Tomasz Wolak, Bioimaging Research Center, World Hearing Center, Institute of Physiology and Pathology of Hearing, 10 Mochnackiego Street, 02-042 Warszawa, Poland, Phone: +48223560349, Email: t.wolak@ifps.org.pl

\begin{abstract}
BACKGROUND: Despite rapid developments in fMRI, there is still ongoing debate on the optimal paradigm for evaluating the level of auditory cortex activation.

MATERIAL AND METHODS: A number of modern neuroimaging methods can be used to assess brain responses to acoustic stimulation, but new paradigms are still needed. Here the sparse fMRI approach is used to examine frequency-specific activation in auditory cortex in 12 normal hearing individuals.

RESULTS: The size of activation expanded with increasing sound intensity and decreasing sound frequency. At the same time, the main site of frequency-specific activation remained the same across intensities, indicating fixed tonotopic organization. The findings of the study are explained in terms of basilar membrane phenomena such as the travelling wave pattern and spread of activation.

CONCLUSIONS: Stimulation levels of at least $60 \mathrm{~dB}$ are necessary in order to obtain robust maps of group activation in auditory cortex. KEY WORDS: functional magnetic resonance imaging, auditory cortex, sound intensity

\section{IMPACTO DE LA INTENSIDAD SONORA SOBRE LA ACTIVACIÓN EN LA CORTEZA AUDITIVA}

\section{Resumen}

INTRODUCCIÓN: Pese al rápido desarrollo de la disciplina, sigue debatiéndose el tema de la optimización del paradigma utilizado en la valoración de la activación de la corteza auditiva mediante el método de la resonancia magnética funcional.

MATERIALES Y MÉTODOS: Se había elaborado un paradigma a utilizar en la exploración de la activación de la corteza auditiva por el método sparse fMRI. En el estudio participaron 12 personas con audición normal.

RESULTADOS: Se demostró que la zona activa aumenta conforme se disminuye la frecuencia y se aumenta la intensidad sonora. Por otra parte, la localización principal de la activación relacionada con el rango de frecuencias dado no varía según la intensidad aplicada. Este efecto indica la preservación de la organización tonotópica. Los resultados del estudio han de entenderse en relación a los fenómenos que se desarrollan en la membrana basal, es decir el paso de la onda viajera y la distribución de la activación.

CONCLUSIONES: Para obtener mapas fiables de activación dentro de la corteza auditiva a nivel grupal se sugiere utilizar sonidos de 60 decibelios como mínimo.

PALABRAS CLAVE: resonancia magnética funcional, corteza auditiva, intensidad sonora.

\section{ВЛИЯНИЕ ИНТЕНСИВНОСТИ ЗВУКА НА АКТИВАЦИЮ В СЛУХОВОЙ КОРЕ}

\section{Абстракт}

ВВЕДЕНИЕ: Несмотря на интенсивное развитие области продолжается дискуссия об оптимизации исследовательской парадигмы для оценки активации слуховой коры методом функциональной магнитно-резонансной томографии.

МАТЕРИАЛ И МЕТОД: Современные методы нейровизуализации могут быть использованы для оценки реакции мозга на акустическую стимуляцию, и все еще существует необходимость в разработке новых парадигм исследования. Здесь был применен редкий подход к фМРТ для изучения частотно-специфической активации в слуховой коре у 12 лиц с нормальным слухом. 
РЕЗУЛЬТАТЫ: Исследования показали, что активная область увеличивается с увеличением интенсивности звука и уменьшением частоты звука. При этом основная область возбуждения, связанная с определённым диапазоном частот, оставалась той же, вне зависимости от использованной интенсивности. Данный эффект указывает на сохранение тонотопической организации. Результаты исследования следует объяснять по отношению к явлениям, происходящим на базилярной мембране, таким как картина бегущей волны и распространение возбуждения.

ВЫВОДЫ: Для получения надежных карт активации в слуховой коре на групповом уровне рекомендуется использование звуковой стимуляции на уровне не менее 60 дБ.

Ключевые слова: функциональная магнитно-резонансная томография, слуховая кора, интенсивность звука

\title{
WPLYW INTENSYWNOŚCI DŹWIĘKU NA AKTYWACJĘ W KORZE SŁUCHOWEJ
}

\begin{abstract}
ABSTRAKT
WSTĘP: Mimo szybkiego rozwoju dziedziny, nadal trwa dyskusja na temat optymalizacji paradygmatu badawczego do oceny aktywacji kory słuchowej metodą czynnościowego rezonansu magnetycznego.

MATERIAŁ I METODA: W celu zbadania aktywacji w korze słuchowej, opracowano paradygmat do badania metodą sparse fMRI. W badaniu uczestniczyło 12 osób ze słuchem prawidłowym.

WYNIKI: Wykazano, że obszar aktywny jest tym większy, im niższą częstotliwość oraz wyższą intensywność dźwięku się zastosuje. Jednocześnie główna lokalizacja pobudzenia związana z określonym zakresem częstotliwości pozostawała ta sama niezależnie od zastosowanej intensywności. Efekt ten wskazuje na zachowanie organizacji tonotopowej. Wyniki badania należy rozumieć w odniesieniu do zjawisk zachodzących na błonie podstawnej, tj. przechodzenie fali wędrującej oraz rozchodzenie się pobudzenia.
\end{abstract}

WNIOSKI: W celu uzyskania wiarygodnych map aktywacji w korze słuchowej na poziomie grupowym sugeruje się stosowanie dźwięków na poziomie minimum $60 \mathrm{~dB}$.

SŁOWA KLUCZOWE: czynnościowy rezonans magnetyczny, kora słuchowa, intensywność dźwięku

\section{BACKGROUND}

Functional magnetic resonance imaging (fMRI) has proven a valuable tool for studying central mechanisms of auditory perception. A number of works have been published which use this method to examine the relationship between sound parameters, including frequency and intensity, and activation patterns in the auditory cortex [13]. Notably, it has been shown that tonotopic organisation is preserved throughout the whole auditory system. This means that the systematic tuning of the basilar membrane in the inner ear, with filters tuned sequentially in frequency, is also reflected in the auditory cortex. The area most evidently organised tonotopically is the primary auditory cortex, lying on and around the Heschl gyri (HG) in the superior temporal lobes. Recent fMRI studies in human have indicated a dominant low-frequency field represented laterally on the HG, with high-frequency regions located posteriorally and anteriorally around it [3]. However, the effect of sound intensity has been studied in only a few fMRI works, all showing that higher intensity increases the extent of active regions detected in the auditory cortex (and/or a local BOLD signal change) [2,4-9].

To assess the tonotopic organisation of auditory cortex with high frequency selectivity, quiet stimulation is preferred. Therefore, threshold acoustic stimulation has been applied in animal studies using invasive techniques, such as single-cell recording of auditory neurons $[10,11]$. However, the fMRI method, which can be safely used in human participants, suffers from high background noise and low signal-to-noise ratio. High-field MR scanners generate acoustic noise at levels of up to $100 \mathrm{~dB}$ SPL during gradient switching, together with sound from air conditioning and helium pumps which can produce noise at $65-80 \mathrm{~dB}$ SPL [12]. Due to these limitations, tonotopic fMRI studies need to employ sounds of 50-90 dB SPL $[3,10,13,14]$.
Another strategy is to use special sparse paradigms which present sounds to the participant during the quieter periods between times of loud data acquisition [15-20].

Although the fMRI field is rapidly developing, there is still ongoing debate on the optimal paradigm for evaluating auditory cortex activation. The current study seeks to evaluate the volume and distribution of activated cortical clusters in response to complex tones presented at five central frequencies and three intensities. A unique study paradigm is used, inspired by the work of Humphries and collaborators (2010) [19]. The sound parameters are chosen to reflect the particular peripheral physiological effects of sound intensity, while corresponding to the wide range of frequencies coded on the basilar membrane. A certain trade-off is suggested between elucidating the pattern of frequency processing in auditory cortex and the intrinsic limitations of the fMRI technique.

\section{MATERIAL AND METHODS}

\section{Material}

Twelve right-handed volunteers ( $3 \mathrm{M}, 9 \mathrm{~F}, 36 \pm 11$ years) with normal hearing ( $<20 \mathrm{~dB}$ HL for $0.25-8 \mathrm{kHz}$ ) participated in an fMRI study. All subjects provided written informed consent. The trial was approved by the Bioethical Committee of the Institute of Physiology and Pathology of Hearing and conformed to the Declaration of Helsinki.

\section{MR imaging}

The study was performed at the Bioimaging Research Center at the World Hearing Center of the Institute of Physiology and Pathology of Hearing in Warsaw. Functional and anatomical scans were collected on a Siemens 
Table 1. Results obtained for contrasts of signal $\left(400 \mathrm{~Hz}_{\mathrm{CF}}-6400 \mathrm{~Hz}\right.$ ) vs silence for three sound intensities; FWE $p<0.01$

\begin{tabular}{|c|c|c|c|c|c|c|c|c|c|c|c|c|c|c|c|}
\hline \multirow[b]{2}{*}{ contrast } & \multirow[b]{2}{*}{ hem. } & \multirow[b]{2}{*}{$\begin{array}{c}\text { main } \\
\text { AAL } \\
\text { region }\end{array}$} & \multicolumn{5}{|c|}{$40 \mathrm{~dB}(\mathrm{~A})$} & \multicolumn{4}{|c|}{$60 \mathrm{~dB}(\mathrm{~A})$} & \multicolumn{4}{|c|}{$80 \mathrm{~dB}(\mathrm{~A})$} \\
\hline & & & $\begin{array}{c}\text { region } \\
\text { size } \\
\text { (vox.) }\end{array}$ & $\underset{t \text {-value }}{\max }$ & & $\begin{array}{l}\text { MNI } \\
\text { ordi- } \\
\text { ates } \\
Y, Z)\end{array}$ & $\begin{array}{c}\text { total } \\
\text { cluster } \\
\text { size } \\
\text { (vox.) }\end{array}$ & $\begin{array}{l}\text { region } \\
\text { size } \\
\text { (vox.) }\end{array}$ & $\underset{t \text {-value }}{\max }$ & $\begin{array}{c}\text { MNI } \\
\text { coordi- } \\
\text { nates }\end{array}$ & $\begin{array}{c}\text { total } \\
\text { cluster } \\
\text { size } \\
\text { (vox.) }\end{array}$ & $\begin{array}{l}\text { region } \\
\text { size } \\
\text { (vox.) }\end{array}$ & $\underset{t \text {-value }}{\max }$ & $\begin{array}{l}\text { MNI } \\
\text { coordi- } \\
\text { nates }\end{array}$ & $\begin{array}{c}\text { total } \\
\text { cluster } \\
\text { size } \\
\text { (vox.) }\end{array}$ \\
\hline \multirow{7}{*}{$\begin{array}{c}0.4 \mathrm{kHz} \\
\mathrm{vs} \\
\text { silence }\end{array}$} & \multirow{4}{*}{$\mathrm{R}$} & STL & 147 & 5.84 & 52 & -155 & \multirow{4}{*}{236} & 580 & 7.39 & $50-195$ & \multirow{4}{*}{796} & 1239 & 12.25 & $48-17 \quad 3$ & \multirow{4}{*}{2017} \\
\hline & & $\mathrm{HG}$ & 60 & 5.25 & 52 & -135 & & 122 & 6.98 & $52-23 \quad 5$ & & 235 & 11.77 & $48-16 \quad 6$ & \\
\hline & & MTL & - & - & & - & & - & - & - & & 108 & 6.33 & $66-335$ & \\
\hline & & STP & - & - & & - & & - & - & - & & 93 & 6.7 & $\begin{array}{lll}51 & 4 & -5\end{array}$ & \\
\hline & \multirow{3}{*}{ L } & STL & 209 & 5.53 & -46 & -297 & \multirow{3}{*}{252} & 730 & 8.78 & $\begin{array}{lll}-50 & -17 & 3\end{array}$ & \multirow{3}{*}{890} & 967 & 11.47 & $\begin{array}{lll}-38 & -31 & 11\end{array}$ & \multirow{3}{*}{1615} \\
\hline & & $\mathrm{HG}$ & 34 & 4.3 & -47 & -146 & & 86 & 6.24 & $\begin{array}{lll}-38 & -30 & 10\end{array}$ & & 173 & 11.47 & $\begin{array}{lll}-37 & -30 & 11\end{array}$ & \\
\hline & & MTL & - & - & & - & & - & - & - & & 249 & 7.47 & $\begin{array}{lll}-46 & -29 & 3\end{array}$ & \\
\hline \multirow{7}{*}{$\begin{array}{l}0.8 \mathrm{kHz} \\
\text { vs } \\
\text { silence }\end{array}$} & \multirow{4}{*}{$R$} & STL & 207 & 6.35 & 58 & -73 & \multirow{4}{*}{326} & 615 & 8.25 & $\begin{array}{lll}58 & -7 & 5 \\
\end{array}$ & \multirow{4}{*}{954} & 1103 & 10.93 & $\begin{array}{lll}56 & -9 & 3 \\
\end{array}$ & \multirow{4}{*}{1727} \\
\hline & & $\mathrm{HG}$ & 78 & 5.74 & 52 & -95 & & 170 & 7.96 & $\begin{array}{lll}54 & -7 & 5 \\
\end{array}$ & & 214 & 9.39 & $48-15 \quad 5$ & \\
\hline & & STP & - & - & & - & & - & - & - & & 78 & 6.66 & $\begin{array}{lll}52 & 3 & -7\end{array}$ & \\
\hline & & MTL & - & - & & - & & - & - & - & & 36 & 4.98 & $60-331$ & \\
\hline & \multirow{3}{*}{$\mathrm{L}$} & STL & 182 & 6.17 & -50 & -113 & \multirow{3}{*}{217} & 732 & 8.91 & $-44 \quad-25 \quad 7$ & \multirow{3}{*}{994} & 1070 & 12.56 & $-46-23 \quad 5$ & \multirow{3}{*}{1599} \\
\hline & & $\mathrm{HG}$ & - & - & & - & & 116 & 7.18 & $\begin{array}{lll}-38 & -30 & 10\end{array}$ & & 151 & 10.27 & $\begin{array}{lll}-37 & -30 & 11\end{array}$ & \\
\hline & & MTL & - & - & & - & & - & - & - & & 142 & 7.63 & $-46-231$ & \\
\hline & & STL & 207 & 6.88 & 50 & $-5 \quad-5$ & & 255 & 7.91 & $\begin{array}{lll}54 & -9 & 3\end{array}$ & & 843 & 12.34 & $\begin{array}{lll}54 & -9 & 3\end{array}$ & \\
\hline & $R$ & $\mathrm{HG}$ & 48 & 5.31 & 54 & -95 & 303 & 89 & 7.6 & $54 \quad-9 \quad 5$ & 396 & 232 & 11.57 & $54 \quad-7 \quad 5$ & 1427 \\
\hline $\begin{array}{c}1.6 \mathrm{kHz} \\
\text { vs }\end{array}$ & & STP & - & - & & - & & - & - & - & & 39 & 8.74 & $\begin{array}{lll}50 & 3 & -7\end{array}$ & \\
\hline silence & & STL & 182 & 6.32 & -50 & -257 & & 246 & 6.01 & $\begin{array}{lll}-58 & -21 & 9\end{array}$ & & 808 & 10.31 & $\begin{array}{lll}-46 & -21 & 1\end{array}$ & \\
\hline & L & $H G$ & - & - & & - & 206 & 42 & 5.49 & $\begin{array}{lll}-34 & -31 & 13\end{array}$ & 326 & 177 & 9.26 & $\begin{array}{lll}-37 & -30 & 11\end{array}$ & 1207 \\
\hline & & STL & 44 & 6.7 & 50 & $1-7$ & & 243 & 7.58 & $\begin{array}{lll}64 & -26 & -41\end{array}$ & & 755 & 10.20 & $52-113$ & \\
\hline $3.2 \mathrm{kHz}$ & $R$ & $\mathrm{HG}$ & - & - & & - & 73 & 79 & 6.2 & $\begin{array}{lll}38 & -25 & 11\end{array}$ & 376 & 206 & 8.35 & $50-13 \quad 5$ & 1237 \\
\hline & & STP & - & - & & - & & - & - & - & & 39 & 6.34 & $\begin{array}{lll}51 & 4 & -5\end{array}$ & \\
\hline & $\mathrm{L}$ & STL & 53 & 5.48 & -48 & $-11-1$ & 62 & 167 & 7.54 & $\begin{array}{lll}-58 & -23 & 9\end{array}$ & 302 & 684 & 7.77 & $\begin{array}{lll}-44 & -17 & 1\end{array}$ & 1029 \\
\hline & $\mathrm{L}$ & $\mathrm{HG}$ & - & - & & - & 02 & 87 & 7.58 & $\begin{array}{lll}-36 & -27 \quad 11 \\
\end{array}$ & 302 & 143 & 7.73 & $-34 \quad-29 \quad 11$ & 1029 \\
\hline & & STL & - & - & & - & & 99 & 5.88 & $\begin{array}{llll}48 & -13 & -3\end{array}$ & 12 & 712 & 9.98 & $46-15-1$ & בר \\
\hline $6.4 \mathrm{kHz}$ & R & $\mathrm{HG}$ & - & - & & - & & - & - & - & 123 & 200 & 8.93 & $\begin{array}{lll}37 & -26 & 11\end{array}$ & 1123 \\
\hline $\begin{array}{l}\text { Vs } \\
\text { silence }\end{array}$ & & STL & - & - & & - & & 75 & 6.51 & $-40-24 \quad 4$ & & 577 & 8.3 & $\begin{array}{lll}-42 & -35 & 13\end{array}$ & \\
\hline & L & $H G$ & - & - & & - & & 44 & 4.66 & $\begin{array}{lll}36 & -25 & 11\end{array}$ & 154 & 121 & 7.16 & $\begin{array}{lll}-34 & -27 & 9\end{array}$ & 864 \\
\hline
\end{tabular}

Hem. - brain hemisphere; $\mathrm{R}$ - right, $\mathrm{L}$ - left; $\mathrm{AAL}$ - Automatic Anatomical Labelling brain atlas; STL - superior temporal lobe; HG - Heschl gyrus; STP - superior temporal pole; MTL - medial temporal lobe; MNI - Montreal Neurological Institute brain atlas

3T Magnetom Trio scanner using a 12-channel head matrix coil.

The scanner produced noise of up to about $98 \mathrm{~dB}$ SPL during gradient switching, and the air conditioning system, helium pumps, and radio-frequency pulses were present permanently and reached levels of up to 65-80 dB SPL. Special headphones attenuated the noise by 15$20 \mathrm{~dB}$. Because the current study focused on auditory responses, a sparse paradigm was employed for functional imaging. During 10 seconds of Time of Repetition (TR), sounds were presented for 8 seconds in relative silence; the remaining 2 seconds were for data acquisition. A single-shot GE-EPI technique was applied with the following parameters: $\mathrm{TR}=10 \mathrm{~s}$, time of echo $(\mathrm{TE})=30 \mathrm{~ms}$, time of acquisition $(\mathrm{TA})=8: 09 \mathrm{~min}$, matrix $=96 \times 96$, field of view $(\mathrm{FOV})=192 \times 192 \mathrm{~mm}$, no of slices $=28$, voxel size $=2 \times 2 \times 2 \mathrm{~mm}$, pixel bandwidth $=1447 \mathrm{~Hz} /$ pix, $\mathrm{iPAT}=2$. In one fMRI session ( 3 runs), 144 brain volumes were collected ( 24 for each of 5 complex tones and silence). Acquisition of one volume (28 slices) took 2 seconds. fMRI data was obtained in the temporal plane in an axial direction; the imaged slab was $6 \mathrm{~cm}$ thick $(3 \mathrm{~cm}$ up and $3 \mathrm{~cm}$ down from the individually localised superior temporal gyrus).

After fMRI, anatomical brain structures were assessed with several high-resolution MRI sequences. The main sequence, T1-MPR, was registered isometrically in the sagittal plane with the following parameters: $\mathrm{TR}=1900$ $\mathrm{ms}$, $\mathrm{TE}=2.26 \mathrm{~ms}$, inversion time $=900 \mathrm{~ms}$, flip angle $(\mathrm{FA})=9^{\circ}, \mathrm{FOV}=28.8 \times 27.0 \mathrm{~cm}$, matrix $=320 \times 300$, slice thickness $=0.9 \mathrm{~mm}$, voxel size $=0.9 \times 0.9 \times 0.9$ $\mathrm{mm}$, pixel bandwidth $=200 \mathrm{~Hz} /$ pix, no of slices $=208$, $\mathrm{TA}=5: 11 \mathrm{~min}$.

\section{Auditory stimulation}

Complex tones with five central frequencies were used: $400 \mathrm{~Hz}_{\mathrm{CF}}, 800 \mathrm{~Hz}_{\mathrm{CF}}, 1600 \mathrm{~Hz}_{\mathrm{CF}}, 3200 \mathrm{~Hz}_{\mathrm{CF}}$, and $6400 \mathrm{~Hz}_{\mathrm{CF}}$ 


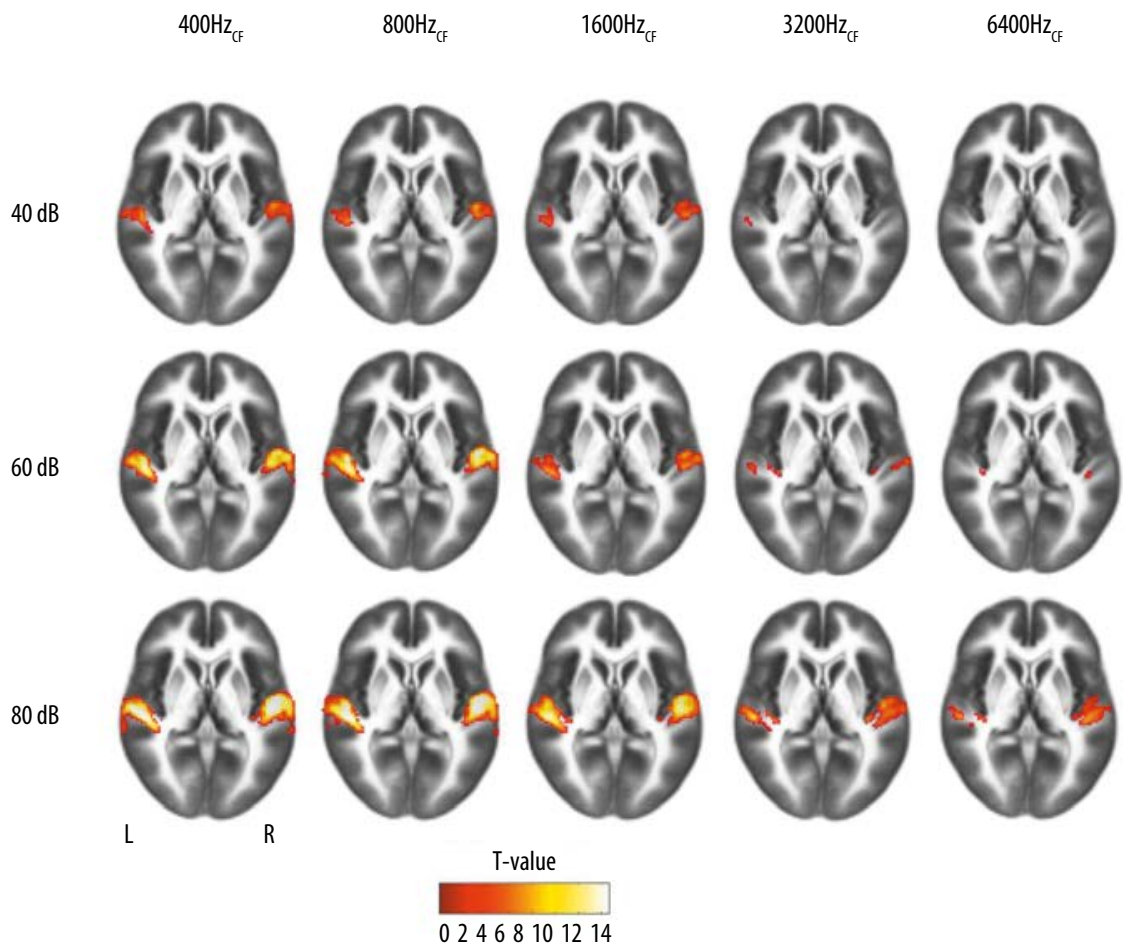

Figure 1a. Results obtained for contrasts of signal $\left(400 \mathrm{~Hz}_{\mathrm{CF}}-6400 \mathrm{~Hz}_{\mathrm{CF}}\right)$ vs silence for three sound intensity levels; FWE $p<0.05$

[19]. Each tone was 8 seconds long and included 80 periods of sound lasting $100 \mathrm{~ms}$ ( $10 \mathrm{~ms}$ rise time, $80 \mathrm{~ms}$ flat, $10 \mathrm{~ms}$ fall time). These 8 -s periods were randomly alternated with 8 -s periods of silence. Complex tones were used instead of constant and monotonous stimuli which cause faster decline of neuronal responses [19, 21-25]. One fMRI run was 8:33 min in duration in which each tone and silence were presented 8 times. The order of stimuli presentation was optimised using a Genetic Algorithm (OptimizeDesign, Tor Wager, URL: http://wagerlab.colorado.edu/tools). Each subject participated in three $\mathrm{fMRI}$ runs for each sound pressure level, $40 \mathrm{~dB}(\mathrm{~A})$, $60 \mathrm{~dB}(\mathrm{~A})$, and $80 \mathrm{~dB}(\mathrm{~A})$ (nine runs in total). Each single sound intensity was tested on a different day and the order was randomised across subjects.

Sounds were delivered via electrodynamic headphones which attenuated the scanner noise by approximately $20 \mathrm{~dB}$ (Confon $\mathrm{GmbH})$. Sound intensity and harmonic distortion were regularly monitored with a GRAS calibration system (Audiometer Calibration Analyzer HW1001). All tones were stored as 16-bit $44.1 \mathrm{kHz}$ digital waveforms. Participants were required to stay still in the bore and listen to the tones. For eye fixation a cross was presented in MRI-compatible goggles.

\section{fMRI data analysis}

fMRI data analysis was performed with Matlab and the Statistical Parametrical Mapping package (SPM 12, Wellcome Department of Cognitive Neurology, London, UK).

Pre-processing involved quality assurance and removal of images with spike artefacts or field distortions, estimation of temporal SNR and image intensity correction, slice-timing (adjustment of time series for each slice to the first slice), re-alignment (e.g. head movement correction using three $3 \mathrm{D}$ rigid body translations and rotations), scrubbing (additional head movement correction when movement exceeded $0.5 \mathrm{~mm}$ between volumes), co-registration of structural images to functional images, segmentation of the T1 structural image into tissue types, normalisation of individual MR T1 images to the Montreal Neurological Institute (MNI) stereotaxic space, smoothing using a $4 \mathrm{~mm}$ FWHM Gaussian filter, global intensity normalisation across sessions, and high-pass filtering to remove lowfrequency physiological noise and signal drift.

Statistical analysis of individual data (1st-level analysis) was performed using general linear modelling (GLM). A GLM model was computed for each person and each fMRI session separately, using pre-processed functional images. For each person onset times of the presented complex tones and silent periods were implemented to the model, followed by model estimation (i.e. a correlation analysis between the time series of neuronal responses, the model series, and the canonical hemodynamic response function in each brain voxel separately). For each intensity level the results were averaged across three sessions. The last step of the individual analysis was designing contrast images (one-sample t-tests) comparing experimental conditions with one another, i.e. $400 \mathrm{~Hz}_{\mathrm{CF}}$ vs silence; $800 \mathrm{~Hz}_{\mathrm{CF}}$ vs silence; $1600 \mathrm{~Hz}_{\mathrm{CF}}$ vs silence; $3200 \mathrm{~Hz}_{\mathrm{CF}}$ vs silence; $6400 \mathrm{~Hz}_{\mathrm{CF}}$ vs silence. The subsequent group data analysis (2nd-level analysis) was performed for the same contrast conditions. All procedures were identical for all three intensity levels, 40, 60, and $80 \mathrm{~dB}$ SPL. 


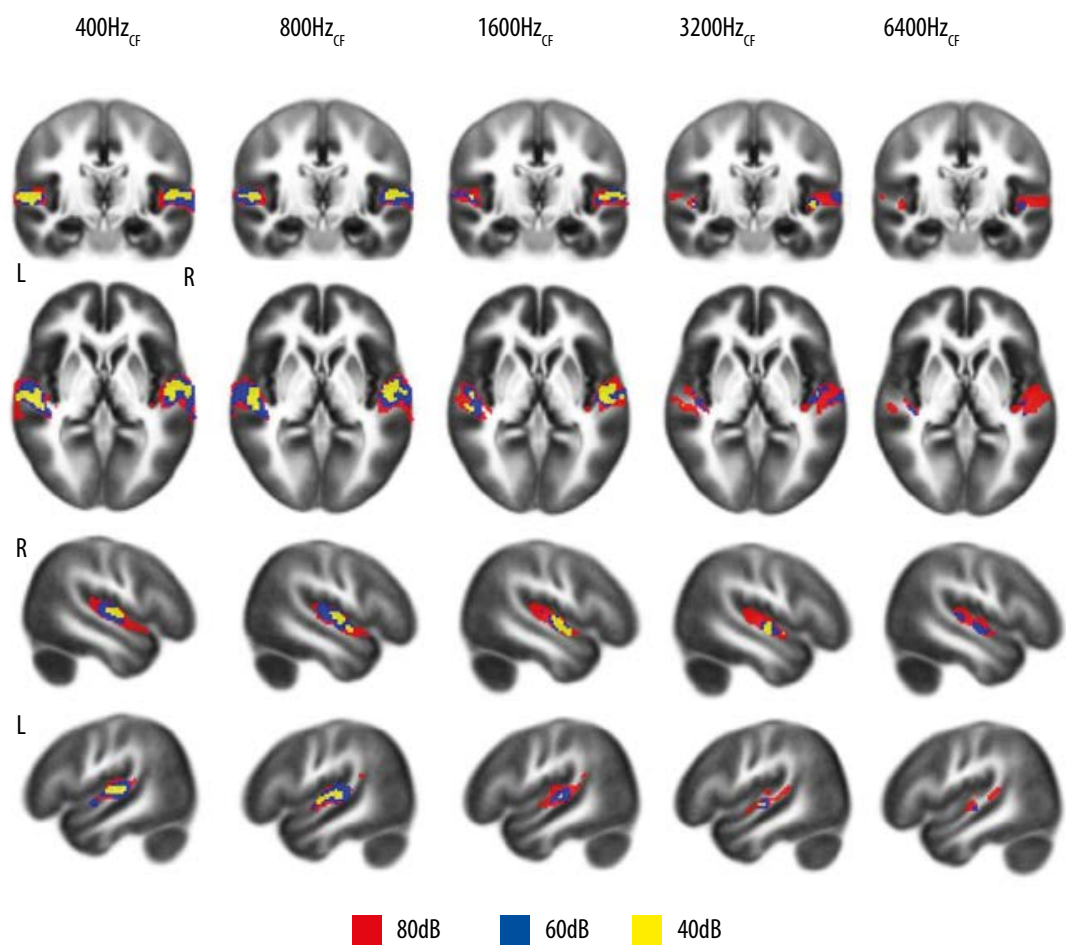

Figure 1b. Results obtained for contrasts of signal $\left(400 \mathrm{~Hz}_{\mathrm{CF}}-6400 \mathrm{~Hz}_{\mathrm{CE}}\right)$ vs silence for three sound intensity levels overlaid; FWE $p<0.05$

\section{RESULTS}

Group outcomes of the study are depicted in Figures 1 and 2 , as well as in Table 1 . The statistical threshold of $p<0.05$ was assumed with familywise-error (FWE) correction for multiple comparisons unless indicated otherwise [26].

Figures $1 \mathrm{a}$ and $1 \mathrm{~b}$ show group outcomes (one-sample $\mathrm{t}$ tests) for the five complex tones presented on various days at three intensity levels. Figure 2 plots the relationship between the intensity level and the size of active clusters revealed in auditory cortex. Table 1 includes data complementing Figures 1 and 2. In the table, the anatomical location and size of each active cluster have been listed, together with their maximum $t$-values and MNI coordinates.

All outcomes indicate that for each sound level and for all frequency ranges, activation was demonstrated in

bilateral superior temporal lobes (except for $6400 \mathrm{~Hz}_{\mathrm{CF}}$ presented at $40 \mathrm{~dB}$ which produced no activation above threshold). The cluster of activation corresponding to low-frequency sounds was centered on the lateral surface of the HG. Gradients of high-frequencies broke into small regions along the posterior and anterior side of medial HG. For the $80 \mathrm{~dB}$ intensity, and to a limited extent for $60 \mathrm{~dB}, 3200 \mathrm{~Hz}_{\mathrm{CF}}$ and $6400 \mathrm{~Hz}_{\mathrm{CF}}$ frequency gradients bifurcated around $\mathrm{HG}$ in a $\mathrm{V}$-shape. The revealed regions included bilateral $\mathrm{HG}$ for $400 \mathrm{~Hz}_{\mathrm{CF}}$ for all three intensities, for $400-1600 \mathrm{~Hz}_{\mathrm{CF}}$ for $40 \mathrm{~dB}$, for $800-3200 \mathrm{~Hz}_{\mathrm{CF}}$ for $60 \mathrm{~dB}$ and $80 \mathrm{~dB}$, and $6400 \mathrm{~Hz}_{\mathrm{CF}}$ for $80 \mathrm{~dB}$. In addition, activity in right STP was present for $400-3200 \mathrm{~Hz}_{\mathrm{CF}}$ when sounds were presented at $80 \mathrm{~dB}$, as well as bilateral MTL for $400-800 \mathrm{~Hz}_{\mathrm{CF}}$ presented at $80 \mathrm{~dB}$. With increasing intensity, the area spread laterally, as well as in the inferior and superior directions in temporal lobes. As shown in Figure 2, the effect was most evident when moving

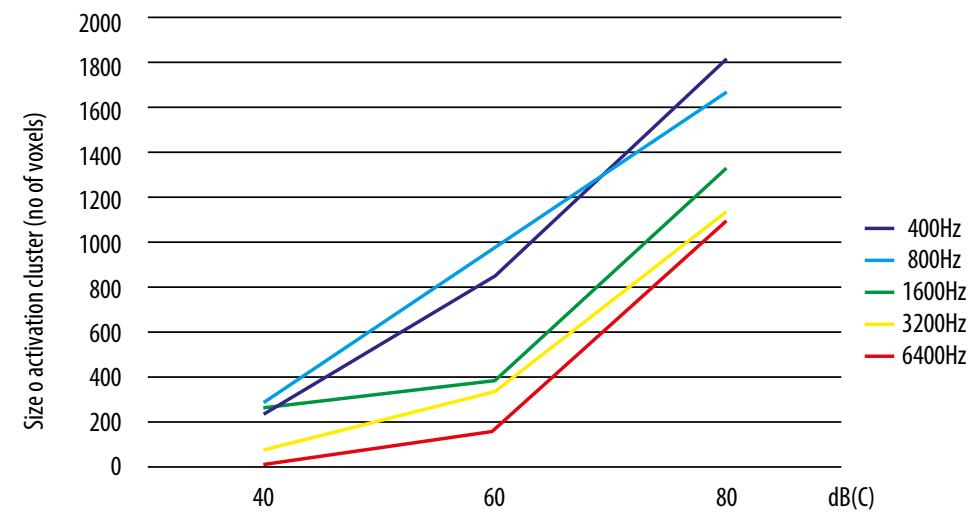

Figure 2. Relationship between sound intensity level (40-80 dB) and active volume size in the auditory cortex. The number of revealed voxels was averaged for both hemispheres across all participants (FDRc, 0.001) 
from 60 to $80 \mathrm{~dB}$ SPL - here the slope of the function is steepest. As can be seen in Figure 1b, however, regions showing up for low-intensity sounds were surrounded by regions responsive to high-intensity sounds. Nevertheless, voxels with the most statistically significant activity were localized in similar locations in the superior temporal lobes (see Table 1). There was, furthermore, an overall tendency for the area to diminish as the central frequency of the presented tone increased. This effect was evident for all three sound levels.

\section{DISCUSSION}

The study shows that preference of certain regions in the auditory cortex for sounds of low or high frequency is preserved regardless of intensity level. There are two tonotopic progressions shown on the rostral and caudal banks of the HG and for louder stimulation activation is only more extensive and spatially less specific. The location of peak activation is preserved across all intensity levels. Similar outcomes have been presented in fMRI studies by Hart and collaborators (2002) [6] and Sigalovsky and Melcher (2006) [9] who showed the same location of activity for a given frequency range at increased intensity levels with simultaneous spatial expansion of active regions. The high-frequency gradient forming a Vshape around the HG, revealed here for intensities $60 \mathrm{~dB}$ and $80 \mathrm{~dB}$, has been reported in numerous papers using the fMRI technique to study auditory cortical responses $[1,2,14,18,19,24,25,27-31]$.

There are several peripheral mechanisms responsible for the central effects of increasing intensity of the perceived sound. Intensity is mainly reflected in the number of impulses per second travelling via the auditory nerve, i.e. the firing rate. For low-level stimulation, i.e. below 40 $\mathrm{dB}$ SPL, the responses of the basilar membrane are relatively selective and only low-threshold neurons are involved in afferent sound transmission. In that case synchronous neuronal responses occur only every several sound presentations. With increased sound levels, the travelling wave induces deflection of broader regions of the basilar membrane (spread of excitation). Then larger populations of neurons are recruited and more inner hair cell stereocilia shear, including those beyond the preferred frequency range. Therefore the quantity of produced and transmitted neurotransmitters is higher. Also, at some point (around 40-60 dB HL), low-threshold neurons become saturated. When higher sound intensities are reached, high-threshold neurons also start to participate and increase their firing rates $[4,14,25,32-34]$. Although the exact relationship is still under debate, proportionality has been suggested between the average firing rate of cortical neurons and the BOLD signal measured with fMRI $[35,36]$. Furthermore, it seems that cortical blood flow only becomes saturated at sound levels above 90$100 \mathrm{~dB}$ SPL [4-6], which is not the case here. In the current study, significant differences were noted for sound levels of $40 \mathrm{~dB}$ and $80 \mathrm{~dB}$ SPL, as has also been noted in the literature $[6,7,9]$. Furthermore, since the effects of increasing sound intensity are also shown within the area of the HG, this would mean that they also involve primary auditory cortex (see the review by Woods and Alain 2009) [8].
The fact that larger areas of activation were revealed for low frequencies, as compared to high frequencies, can also be explained in terms of physiological mechanisms occurring at the basilar membrane. The travelling wave in the cochlea commences at the base and terminates at the apex. Due to the mechanical features of the basilar membrane, a loud tone of low frequency will in addition stimulate nerve endings at the base of the cochlea, specific for high-frequency sounds. Furthermore, the excitation pattern of the basilar membrane is asymmetrical and spreads more to the high-frequency side which is determined by responses of the low-frequency side of auditory filters with central frequencies exceeding the applied signal frequency [34]. Also, auditory filters are broader for low-frequency sounds [38]. With the preferred frequency still inducing largest local deflections on the basilar membrane, these effects are mostly seen for high-intensity sound levels [33,39-44]. A number of fMRI studies employing sound stimulation have revealed larger and/or stronger activations for lower, as compared to higher frequency ranges $[8,14,19,27-31]$.

In addition, the very limited extent of activity found for $40 \mathrm{~dB}$ SPL sounds might be related to the fact that fMRI studies are never silent. The sounds of the helium pump and air conditioning system are approximately $70 \mathrm{~dB}$ SPL and external headphones can only attenuate the noise by $20 \mathrm{~dB}$. Although the noise of the scanner during data acquisition has been cancelled by using a sparse imaging paradigm, some masking of the experimental stimulation cannot be excluded $[5,16,37]$.

The outcomes of the study indicate that fMRI studies of tonotopic organisation of auditory cortex require sound levels of $60-80 \mathrm{~dB}[4,8,13,18,19,24,25,27,30]$. A sound intensity of $60 \mathrm{~dB}$ SPL can only be used, however, if a relatively large number of subjects participate in the study. Some authors have already suggested that if sounds below $50 \mathrm{~dB}$ SPL are used, statistically significant outcomes are difficult, especially if a stable group effect is to be achieved. The relatively small regions activated by highfrequency sounds, as well as considerable inter-subject location variability, yield a small group effect $[4,14]$. This has been shown in the current study when sounds were played at $40 \mathrm{~dB}$.

In the presented study, intensity has been used as the sound parameter $[19,29,30]$. This is the approach used in most tonotopic fMRI studies, as intensity is relatively easy to control. Some authors do not even use any intensity normalisation $[13,18,24,25,45,46]$. However, it should be noted that, depending on sound parameters such as frequency and time pattern, the hearing lev$e l$ and the perceived loudness can differ among individuals, which in turn can affect the outcomes of an fMRI study. Several procedures have been suggested to balance study conditions across all participants. One way is to normalise all sounds (frequency bands) to one level, using the individual hearing level (SL, sensation level) $[14,47]$. Alternatively, perceived loudness is estimated with respect to a pattern sound (such as e.g. $1000 \mathrm{~Hz}$, and then sounds are presented at normalised sound levels (EL, equal loudness) $[5,31,48]$. Such an approach will be applied in future studies. 
In conclusion, we propose an in-house fMRI paradigm that can be successfully applied to elucidate activation of the auditory cortex in response to a range of frequency bands and intensity levels. The findings confirm the existing literature reports and expand them in that the outcomes are briefly discussed in the frame of psychoacoustic mechanisms. Further recruitment of study participants has been undertaken, including patients with various kinds of sensorineural hearing loss (see Skarżyński et al. (2013) for initial findings in partial deafness) [49]. This will permit the central pathophysiological phenomena occurring in the inner ear to be seen and compared with those from normal hearing subjects.

Funding: This work was supported by Polish National Science Center grant 2012/05/N/NZ4/02 awarded to Dr. Katarzyna Cieśla.

\section{References}

1. Wolak T, Cieśla K, Lorens A, Kochanek K, Lewandowska M, Rusiniak M, Pluta A, Wójcik J, Skarżyński H. Tonotopic organisation of the auditory cortex in sloping sensorineural hearing loss. Hear Res 2017;355:81-96.

2. Woods DL, Stecker GC, Rinne T, Herron TJ, Cate AD, Yund EW, Liao I, Kang X. Functional maps of human auditory cortex: effects of acoustic features and attention. PloS One 2009;4(4):e5183.

3. Saenz M, Langers DRM. Tonotopic mapping of human auditory cortex. Hear Res 2014; 307:42-52.

4. Jaencke L, Shah J, Posse S, Grosse-Ryuken R, Mueller-Gaertner HU. Intensity coding of auditory stimuli. Neuropsychol 1998;38(9):875-883.

5. Langers DR, van Dijk P, Schoenmaker ES, Backes WH. fMRI activation in relation to sound intensity and loudness. Neuroimage 2007;35(2),709-718.

6. Hart H, Palmer A, Hall D. Heschl's gyrus is more sensitive to tone level than non-primary auditory cortex. Hear Res 2002;171:177-179.

7. Brechmann A, Baumgart F, Scheich H. Sound-level-dependent representation of frequency modulations in human auditory cortex: a low-noise fMRI study. J Neurophysiol 2002;87(1):423-433.

8. Woods DL, Alain C. Functional imaging of human auditory cortex. Curr Opin Otolaryngol. Head Neck Surg 2009;17:407-411.

9. Sigalovsky IS, Melcher JR. Effects of sound level on fMRI activation in human brainstem, thalamic and cortical centers. Hear Res 2006;215:67-76.

10. Recanzone GH, Guard DC, Phan ML. Frequency and intensity response properties of single neurons in the auditory cortex of the behaving macaque monkey. J Neurophysiol 2000;83:2315-2331.

11. Tsukano H, Horie M, Ohga S, Takahashi K, Kubota Y, Hishida $\mathrm{R}$, Takebayashi H, Shibuki K. Reconsidering tonotopic maps in the auditory cortex and lemniscal auditory thalamus in mice. Front Neural Circuits 2017;11:14.

12. Ravicz ME, Melcher JR, Kiang NY. Acoustic noise during functional magnetic resonance imaging. J. Acoust. Soc Am 2000,108,1683-1696.

13. Formisano E, Kim DS, Di Salle F, van de Moortele PF, Ugurbil K, Goebel R. Mirror-symmetric tonotopic maps in human primary auditory cortex. Neuron 2003,40,859-869.

14. Langers DR, van Dijk P. Mapping the tonotopic organisation in human auditory cortex with minimally salient acoustic stimulation, Cereb Cortex 2011,22,2024-2038.

15. Edmister WB, Talavage TM, Ledden PJ, Weisskoff RM. Improved auditory cortex imaging using clustered volume acquisitions. Hum Brain Map 1999;7(2):89-97.

16. Hall DA, Haggard MP, Akeroyd MA, Palmer AR, Summerfield AQ, Elliot MR, Gurney EM, Bowtell RW. "Sparse" temporal sampling in auditory fMRI. HBM 1999,7,213-223.
17. Burton H, Firszt JB, Holden T, Agato A, Uchanski RM. Activation lateralization in human core, belt, and parabelt auditory fields with unilateral deafness compared to normal hearing. Brain Res 2012,1454,33-47.

18. Herdener M, Esposito F, Scheffler K, Schneider P, Logothetis NK, Uludag K, Kayser C. Spatial representations of temporal and spectral sound cues in human auditory cortex. Cortex 2013;49(10):2822-2833.

19. Humphries C, Liebenthal E, Binder JR. Tonotopic organisation of human auditory cortex. Neuroimage 2010;50(3):1202-1211.

20. Langers DR, Sanchez-Panchuelo RM, Francis ST, Krumbholz K, Hall DA. Neuroimaging paradigms for tonotopic mapping (II): the influence of acquisition protocol. Neuroimage 2014,100,663-675.

21. Langers DR, Backes WH, van Dijk P. Spectrotemporal features of the auditory cortex: the activation in response to dynamic ripples, Neuroimage 2003,20,265-275.

22. Rauschecker JP, Tian B. Mechanisms and streams for processing of "what" and "where" in auditory cortex. PNAS 2000,97(22),11800-11806.

23. Wessinger CM, VanMeter J, Tian B, Van Lare J, Pekar J, Rauschecker JP. Hierarchical organisation of the human auditory cortex revealed by functional magnetic resonance imaging. J Cogn Neurosci. 2001,13(1),1-7.

24. Hertz U, Amedi A. Disentangling unisensory and multisensory components in audiovisual integration using a novel multifrequency fMRI spectral analysis. Neuroimage 2010,52(2),617-632.

25. Striem-Amit E, Hertz U, Amedi A. Extensive cochleotopic mapping of human auditory cortical fields obtained with phase-encoded fMRI. PLoS One 2011,6,e17832.

26. Shaffer JP. Multiple hypothesis testing. Ann Rev Psychol 1995,46:561-584

27. Seifritz E, Di Salle F, Esposito F, Herdener M, Neuhoff JG, Scheffler K. Enhancing BOLD response in the auditory system by neurophysiologically tuned fMRI sequence. Neuroimage 2006,29(3),1013-1022.

28. Barton B, Venezia JH, Saberi K, Hickok G, Brewer AA. Orthogonal acoustic dimensions define auditory field maps in human cortex. Proc Natl Acad Sci USA 2012,109(50),20738-20743.

29. Da Costa S, van der Zwaag W, Marques JP, Frackowiak RSJ, Clarke S, Saenz M, Human primary auditory cortex follows the shape of Heschl's gyrus. J Neurosci 2011,31,14067-14075.

30. Da Costa S, van der Zwaag W, Miller LM, Clarke S, Sae$\mathrm{nz}$ M. Tuning into sound: frequency-selective attentional filtering in human primary auditory cortex. J Neurosci 2013,33(5),1858-1863.

31. Moerel M, DeMartino F, Formisano E. Processing of Natural Sounds in Human Auditory Cortex: Tonotopy, Spectral Tuning, and Relation to Voice Sensitivity. J Neurosci 2012, 32(41),14205-14216.

32. Hamill T, Price L. The Hearing Sciences. Plural Publishing; 2008. 
33. van Békésy G. Some biophysical experiments from fifty years ago. Ann Rev Physiol 1974,36,1-18.

34. Moore BCJ, Glasberg BR, Baer T. A model for the prediction of thresholds, loudness and partial loudness. J Audio Eng Soc 1997,45,224-240.

35. Rees G, Friston K, Koch C. A direct quantitative relationship between the functional properties of human and macaque V5. Nat Neurosci 2000,3,716-723.

36. Ogawa S, Tank DW, Menon R, Ellermann JM, Kim SG, Merkle $\mathrm{H}$, Ugurbil $\mathrm{K}$. Intrinsic signal changes accompanying sensory stimulation: functional brain mapping with magnetic resonance imaging. Proc Natl Acad Sci USA, 1992,89,5951-5955.

37. Langers DR, van Dijk P, Backes WH. Interactions between hemodynamic responses to scanner acoustic noise and auditory stimuli in functional magnetic resonance imaging. Magn Reson Med 2005,53(1),49-60.

38. Glasberg BR, Moore BCJ. Frequency selectivity as a function of level and frequency measured with uniformly exciting notched noise. J Acoust Soc Am 2000,108:2318-2328.

39. Lutfi RA, Patterson RD. On the growth of masking asymmetry with stimulus intensity. J Acoust Soc Am 1984,t.76,739-745.

40. Patterson RD, Moore BCJ. Auditory filters and excitation patterns as representations of frequency resolution, in Frequency Selectivity in Hearing. London, BCJ Moore Academic, 1986.

41. Moore BCJ, Glasberg BR. Formulae describing frequency selectivity as a function of frequency and level and their use in calculating excitation patterns. Hear Res 1987,28,209-225.
42. Glasberg BR, Moore BCJ. Derivation of auditory filter shapes from notched-noise data. Hear Res 1990,47,103-138.

43. Rosen S, Baker RJ, Kramer S. Characterizing changes in auditory filter bandwidth as a function of level. Auditory Physiology and Perception, Pergamon Oxford edited by Cazals Y, Horner K, Demany L. 1992.

44. Rosen S, Baker .J, Darling A. Auditory filter nonlinearity at $2 \mathrm{kHz}$ in normal hearing listeners. J Acoust Soc Am 1998,103,2539-2550.

45. Schonwiesner M, von Cramon DY, Rubsamen R. Is it tonotopy after all? Neuroimage 2002,17(3),1144-1161.

46. Paltoglou AE, Christian J, Sumner A, Deborah A. Hall Examining the role of frequency specificity in the enhancement and suppression of human cortical activity by auditory selective attention. Hearing Research 2009, 257,106-118.

47. Talavage TM, Sereno MI, Melcher JR, Ledden PJ, Rosen BR, Dale AM. Tonotopic organisation in human auditory cortex revealed by progressions of frequency sensitivity. J Neurophysiol 2004,91(3),1282-1296.

48. Scarff CJ, Dort JC, Eggermont JJ, Goodyear BG. The Effect of MR Scanner Noise on Auditory Cortex Activity using fMRI. HBM; 2004,22,341-349.

49. Skarżyński PH, Wolak T, Skarżyński H, Lorens A, Śliwa L, Rusiniak M, Pluta A, Lewandowska M, Ciesla K, Jędrzejczak WW, Olszewski $Ł$. Application of the functional magnetic resonance imaging fMRI for the assessment of the primary auditory cortex function in partial deafness patients: a preliminary study. Int Adv Otol 2013,9(2),153-160. 